\title{
The Role of Government Intervention as a Moderating Variable in the Relationship between Entrepreneurial Networks and Business Owners' Performance in Jordan
}

\author{
Haitham Alhnaity ${ }^{1}$ \\ Ayed Almuala ${ }^{2}$ \\ Ali Kh Elmasri ${ }^{3}$ \\ 'COB College, UUM Sintok, Malaysia \\ Email:haithmalhunity@gmail.com Tel:00962797518118 \\ Zarqa University, Jordan \\ ${ }^{3}$ Ministry of finance, Jordan
}

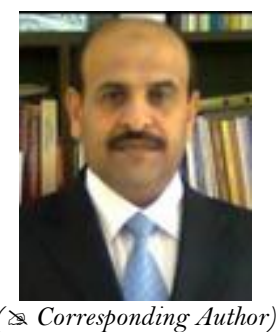

\begin{abstract}
This study built on a sample of 384 small businesses located in the central area of Jordan. We perform an analysis of the influence of entrepreneurial networks on small business performance. The purpose of this study was to test and demonstrate empirically the role of government as a moderating variable in the relationship between entrepreneurial networks and small business owners' performance. The population of this study is small business owners who have participated in ERADA program of as much as 4906 small business. These results indicate that entrepreneurial networks have a significant effect on the performance of the small business owners. It provides an empirical explanation that entrepreneurial networks and government intervention can contribute to the improvement of small business owners' performance while the government's role is not proven moderate the relationship between entrepreneurial networks and small business owners' performance. The significant positive effects of entrepreneurial networks suggest that this variable is important in enhancing small business owners' performance. As such, small business owners should be inculcated with these entrepreneurial networks. In addition, government intervention should take into consideration of entrepreneurial networking when designing and conducting any entrepreneurship program.
\end{abstract}

Keywords: Entrepreneurial networks, Government intervention and small business owners' performance.

JEL Classification: L25; L26.

Citation | Haitham Alhnaity; Ayed Almuala; Ali Kh Elmasri (2018). The Role of Government Intervention as a Moderating Variable in the Relationship between Entrepreneurial Networks and Business Owners' Performance in Jordan. Asian Journal of Economics and Empirical Research, 5(1): 93-98.

History:

Received: 23 July 2018

Revised: 13 August 2018

Accepted: 15 August 2018

Published: 17 August 2018

Licensed: This work is licensed under a Creative Commons

Attribution 3.0 License (cc) Br

Publisher: Asian Online Journal Publishing Group
Contribution/Acknowledgement: All authors contributed to the conception and design of the study.

Funding: This study received no specific financial support.

Competing Interests: The authors declare that they have no conflict of interests.

Transparency: The authors confirm that the manuscript is an honest, accurate, and transparent account of the study was reported; that no vital features of the study have been omitted; and that any discrepancies from the study as planned have been explained.

Ethical: This study follows all ethical practices during writing.

\section{Contents}

1. Introduction

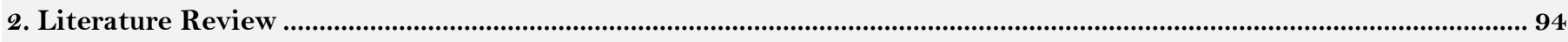

3. Relationship between Entrepreneurial Networks and Small Business Performance .................................................. 95

4. Government Intervention as Moderator Variable on the Relationship between Entrepreneurial Networks and Small

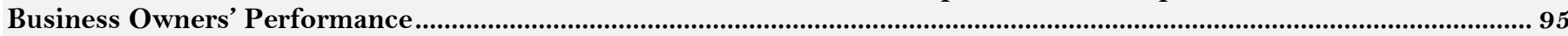

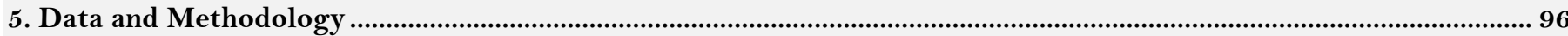

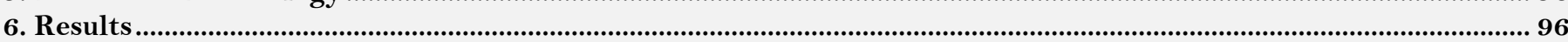

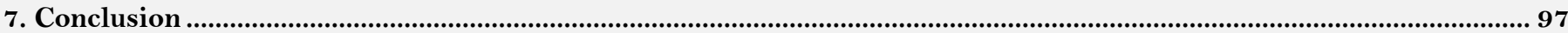

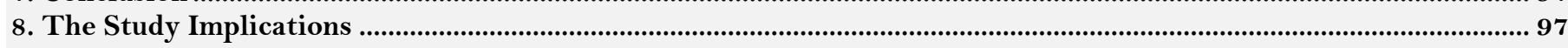

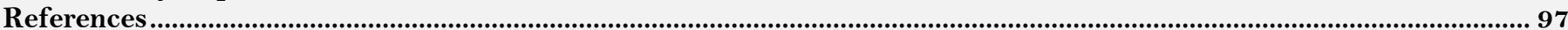




\section{Introduction}

Owners usually engage with their projects by presenting ideas, knowledge, and competence to operate their business, nevertheless, they want complementary resources to produce and deliver their goods or services (Hasanov et al., 2014). They obtain provision, knowledge, and access to distribution channels through their social networks. Entrepreneurs are also linked to people and organizations that interact among themselves and these contacts can widen the availability of resources that can maintain a new firm (Greve and Salaff, 2003).

Available literature asserted that entrepreneurs' networks are indeed an opportunity set, which reflected the reach information, knowledge and access to resources for entrepreneurs. However, academics exposed an increasing appreciation of the efficacy, use, and importance of entrepreneurial networks (Hasanov et al., 2014). In relation to this, past studies (Batjargal, 2010) reported that individual's social resources can bring about the acknowledgment of opportunities, in addition to or distinct from special personal resources possessed.

The entrepreneurial drive is influenced by social networks through resource access that is difficult to achieve via formal channels. An entrepreneur searches for knowledge and the key to knowledge acquisition is access to such social networks. Upon acquiring more knowledge, the entrepreneur has a greater probability of being successful in his innovative activity. According to the social network perspective, the individual's behavior is determined by the pattern of relationships wherein they are integrated. In regards to this, the recent theories on work design aimed to comprehend the structure of interpersonal relationship and how it creates organizational outcomes like individual performance (Kang and Snell, 2009).

\section{Literature Review}

\subsection{Small Business Owners’ Performance}

Generally speaking, small businesses are run by their owners, who are also their founders, their establishers and the ones who manage them. Such owner decides the substance of business, the market to enter, and the goods and services to deliver. In essence, the owners and their ideas, a way of thinking, social capital and attitude are important for the successful small business performance as each business requires a driving force just as a plane needs a pilot (Walker and Brown, 2004). Moreover, each small business values and performance stem from its owner, where owners noted the significant items in terms of financial and non-financial measures that they generally utilized to gauge their small business performance.

For the measurement of successful performance of small businesses, there are thus non-financial and financial criteria used and for their sustenance and performance, it is crucial for small business owners to promote their entrepreneurial spirit. In the context of most small businesses, small business owners (SBOs) work around the clock and it can be reasonably stated that most of the business decisions rest on their shoulders, either solely or among partners (Walker and Brown, 2004).

The most common metrics used to measure organizational performance are profitability and growth. The data gathered can be objective (actual amount) or subjective (perception). Given the competitive nature and market dynamics of small businesses, and the difficulty of gaining access to past financial data from many of them, most research in this area has relied on a survey-based approach to measure performance (Arslan and Staub, 2013). In most cases, the performance of the firm is measured by the perception of the owner or manager providing responses to the survey (Davis et al., 2010). Researchers have reported that owner or manager responses on financial data were highly correlated with the actual data. In this study, we employed the survey approach, asking owners/managers to evaluate organizational performance based on their individual perceptions (Arslan and Staub, 2013).

\subsection{Entrepreneurial Networks}

Small businesses cannot achieve their goals on their own and for this, they need support and resources from other firms and other external actors (Hasanov et al., 2014) supporting entities (business networks) (Khayesi et al., 2014) and relatives and friends (personal networks) (Batjargal, 2010). In this regard, several studies have explained that small firms' success hinges on such supporting networks along with social networks (Batjargal, 2010; Grimaldi et al., 2011). In other words, network relationships enable entrepreneurs to find opportunities and resources in a timely manner (Sadler and Chetty, 2001) indicating that small businesses are really in need of networks. However, prior researches have shown that the most kinds of entrepreneurial networks consist of the social network, business network, and inter-organizational strategic network (Abou-Moghli and Al Muala, 2012).

Entrepreneurial networks help in the acquisition of utilitarian resources and they influence entrepreneurial activity and enhance business performance of owners who take part in social networks as they have a greater rate of success in their businesses (Baron and Markman, 2000). In such a social network, mutual trust among members mitigates entrepreneurial risks, especially in an environment rife with risks (Moran, 2005). However, SMEs can obtain knowledge and skills through networking and eventually achieve competitive advantage, and they can take advantage of the economies of scale (Watson, 2007). In the context of Jordan, SMEs constitute 99.8 percent of businesses and they employ 66.9 percent of employees with an added value of 57.7 percent (UNDP, 2011) but studies in the field of entrepreneurial networks are still few and far between.

Social interaction enables the firm to determine and exploit opportunities and to oversee the uncertainties in the environment (Elfring and Hulsink, 2003). Added to this, networking allows firms access to both knowledge and resources within the limited time and cost (Gulati and Higgins, 2003). Other studies such as Zaheer and Bell (2005) further added that network resources assist firms in developing and supporting their internal capabilities, and this eventually, may improve the performance of the small business.

More importantly, entrepreneurs are more likely to have significant ties with other entrepreneurs rather than non-entrepreneurs at the weak ties in their networks positively relates to subsequent performance indicators and activities of venture development (Davidsson and Honig, 2003). Researchers who dedicated their work to an organizational network used two perspectives to explain the way networks can lead to outcomes and they are structuralist and connectionist perspectives (Borgatti and Foster, 2003). The variables of the former are network size and the network ties strength while the latter has content flowing throughout network relationships. This line 
of questioning attempts to uncover the way actors access resources managed by other actors and these include information, money, power, and, material.

\subsection{Government Intervention}

In this study, the intervention is the perception of the government role in boosting entrepreneurial activities and in directing the development and growth among small business owners. Tilley (1999) defines intervention as actions which can be used by external parties (such as government) to change small business behaviour (e.g. regulation, financial incentives and assistance/education). This justifies the aim of the government intervention wherein the policies stimulating entrepreneurship among small businesses is stressed and the probability of creating a small business climate via policies and environment that is conducive to innovation, employment, and economic growth.

Wagaman and Segal (2014) define government intervention as government-initiated programs and/or funded actions that are intended to support the welfare or well-being of the people who live within its boundaries by promoting entrepreneurship to support small business performance. Meanwhile, intervention denotes several efforts made by the government in various ways in order to encourage the growth, survival and full participation of small-scale enterprises for the country's socio-economic development (Onwukwe and Ifeanacho, 2011; Eniola and Entebang, 2015). For the purposes of this study, the researcher adopted Wagaman and Segal (2014) and Onwukwe and Ifeanacho (2011) definitions.

In this paper, the study aims to determine whether the small business owners are impacted by their entrepreneurial networks while engaging in entrepreneurial processes and activities to generate successful performance and how the role of government can affect the relationship. Virtually all known kinds of government intervention in Jordan has formulated and implemented, different kinds of policies, programs, and procedures to develop the small business were embraced. This indicates the need to focus on government intervention to promote the improvement of small businesses owners' performance.

Few numbers of studies have been conducted to examine the government intervention as a potential moderator on the relationships between performance outcomes and their predictors (Eniola and Entebang, 2015). As such, this calls for additional empirical work on the moderating role of government intervention on the relationship between entrepreneurial networks with small business owners' performance so as to better understand the predicting role of the said construct.

In this study, government intervention was incorporated as a moderator to see if this construct plays a significant role in strengthening or reducing the relationship between entrepreneurial networks with small business owners' performance. Fatoki (2012); Koe (2013); Mason et al. (2015) suggested studying the moderating role of different variables on the entrepreneurship and performance link. However, examining government intervention as a moderator could increase researchers' theoretical understanding and provide them with empirical evidence on how government intervention might be a potential moderator.

\section{Relationship between Entrepreneurial Networks and Small Business Performance}

Authors stated that the entrepreneurial networks are critical and beneficial to small businesses and their owners. On the other hand, there are a few studies dealing with the impact of entrepreneurial networks practice in the success/failure of business On-going stage. Nature and importance of networks to businesses still need more investigation and analysis to provide and determine the reasons behind success and fail in all aspects of entrepreneurial networks especially in on-going stage (Premaratne, 2002; Jack, 2010). Taken into attention the Jordanian small business owner situation these entrepreneurial network kinds articulated the choice of entrepreneurial network kinds explored in this study.

The literature states that networking is the top solution for developing of small firms in less developed countries (LDCs) as it lies between bureaucracy and the market (Borg, 1991). Such network relationships are established by entrepreneurs to acquire the required resources and to carry out activities and in this perspective, the entrepreneurial network comprises four main components, which are actors, resources, activities and linkages. However, many previous studies have examined the relationship between an entrepreneurial network and small business owners' performance (Hasanov et al., 2014; Khayesi et al., 2014).

The main reason to study this linkage is that past studies have found inconsistent findings in small business performance settings, some of the previous studies found a significant relationship between entrepreneurial network and performance (Khayesi et al., 2014). In contrary, a few studies found that there is an insignificant relationship (Hasanov et al., 2014) However, the researcher has found a few studies in Jordan small business setting that included network as a predictor of small business performance. This study presents the conceptual positive relationship between the network and business performance as showed in previous studies, and according to SNT studies, a positive relationship was found between network and performance. However, based on the previous research findings the following hypothesis can be proposed in this study for the empirical testing as follows:

Hypothesis 1: There is a relationship between entrepreneurial networks and small business owners' performance.

\section{Government Intervention as Moderator Variable on the Relationship between Entrepreneurial Networks and Small Business Owners' Performance}

Prior to the date, there is no research examines the moderating effect of governmental interventions toward entrepreneurship adoption in Jordan. However, there were studies such as Mohd Shariff et al. (2010) who tried to study the moderating effects of government interventions in another context. They tried to study the moderating effect of government intervention on entrepreneurship and growth performance of SMEs in Cambodia. They lastly concluded that the government policy does moderate the relationship between entrepreneurial value, management and market practice, and the growth performance of SMEs. Also, Ruslan et al. (2014) conducted a study to examine the technological determinants that may influence SMEs in Malaysia to adopt one of the green innovation methods 
and suggested to explore the influence of government interventions toward the relationship. While there are previous studies found that the government intervention changes and damages investment competence and performance (Chen et al., 2011).

There is no real model of a society run in the absence of government intervention. Even the most extreme libertarian economists would accept there needs to be some state protection of property rights and spending on national defense. The debate comes on the extent of government intervention. This needs to take place in each aspect of government intervention (Moeljadi et al., 2015).

Furthermore, Onwukwe and Ifeanacho (2011) investigate the impact of government intervention on the SMEs growth in Nigeria and found the gap between policy and policy implementation. While there are a few studies were found that government intervention as a moderating effect conducted in Jordan settings in particular. Michael and Pearce (2009) conducted a study relating to the rationale for government involvement in entrepreneurship to promote innovative. In addition to, Eniola and Entebang (2015) reviewed the relationship between government intervention relation to public policy and small business performance; they suggested the importance of adopting procedures and appropriate system that improve small business performance.

Finally reflecting on the views of Zahra and Wright (2011) this study concludes that, by reinforcing the entrepreneur's knowledge base through the implementation of public policies (with the help of government intervention), the relationship between entrepreneurship and economic development could be fortified. So based on theoretical conclusions, the authors of this study further extend their contribution towards the policy implications of this study. Therefore, this study examined the effect of government intervention as a moderating variable between entrepreneurial networks, and small business owners' performance. Thus, the study hypothesis as follows:

H 2: Government intervention moderates the relationship between entrepreneurial networks and small business owners' performance.

\section{Data and Methodology}

Owing to the elusive aspect of collecting a list of small business population in Jordan, the sampling frame for the present study was requested from the ERADA (enhancement of production center) database that organizes the portfolio of 4906 entrepreneurial businesses and is acknowledged to be the top Training consultant, and provider of feasibility studies for small Jordanian businesses. The study sample consists of 2571 small businesses located in the central region of Jordan in the cities of Amman, Albalqa and Azarqa. The middle region was selected as $65 \%$ of the overall small businesses are located in the region. A total sample of 384 was selected from a population of 2571 , to which a self-administered questionnaire was distributed to. Respondents were requested to indicate the level of their agreement or disagreement to the items provided that are gauged through a five-point numerical scale. The scale ranges from 1 depicting strongly disagree to 5 depicting strongly agree. The questionnaire items were adopted from prior studies and modified to suit the context of the study. The data collected were analyzed through SEM-PLS. this study employed a two-step process instead to evaluate and report PLS-SEM results as recommended by Henseler et al. (2009).

\section{Results}

\subsection{Demographic Profile of the Respondents}

In this paper Sample characteristics cover five major items: (1) gender, (2) age, (3) level of education, (4) experience, (5), and training. We achieved these results after analyzing the demographic variables. In the last specimen, $285(69.2 \%)$ of the respondents were guys and $127(30.8 \%)$ were females. It is understood that the larger part of sample recorded $69.2 \%$ were male, and most of the respondent's age fluctuated between 20 - 30 years of age $(27.2 \%)$. With respect to entrepreneurs encounter the lion's share of respondents (27.7\%) were 1-5 years' experience and the most minimal of the respondents were $6-10$ years' experience (11.4 \%). The biggest gathering of entrepreneurs was vocational education level (46.1\%) and the smallest group was PhD level at (0.7\%). On the other hand, looking at the average of operation periods for small businesses in Jordan, the majority of respondents who recorded (44.2\%) operation period for 6- 10 year. Moreover, the majority of employee number recorded $71.8 \%$ (15 ), employee. Finally, the discussion shows that $45.6 \%$ of the respondents located in Amman.

\subsection{Describe of Respondents}

Based on a review of the literature related to the measurement of performance, three objective measures of growth were included: sales growth, increase in the number of employees and increase in profitability over a threeyear period (Rauch et al., 2004; Wiklund and Shepherd, 2005). To assess the level of entrepreneurial networks a five-point Likert's scale was used to measure the (8) items of the entrepreneurial networks; These items were measured based on -1 as strongly disagree to -5 as strongly agree. The researcher used these items adopted from (Premaratne, 2002). Most of these items were modified to suit entrepreneurial networks in small businesses performance settings.

Table-1. Descriptive Statistic of Principle Constructs (N=384)

\begin{tabular}{l|l|l|l|l}
\hline construct & Total items & Mean & Standard Deviation & Level \\
\hline Entrepreneurial networks & 6 & 2.91 & .74 & ML \\
\hline Government intervention & 3 & 2.96 & .88 & ML \\
\hline Small business owners' performance & 5 & 3.00 & .80 & ML \\
\hline
\end{tabular}

According to Table 1 above, 384 valid cases of mean and standard deviation for all the variables were analyzed. The four-point interval scales were categorized into equal-sized categories of low level, moderately low, moderatehigh and high level. Subsequently, the mean scores of less than 3.00 were considered low value, mean scores of 3 to 5 were considered the moderate value and mean scores more than 5 were considered high (Armanurah, 2014) entrepreneurial networks represented by 8 items. Apparently, as shown in Table 1, the mean scores are considered 
moderate low (2.91), also the government intervention variable is at a moderate low level (2.96). The high mean scores imply that respondents agree that these variables influence small business owners' performance.

Overall, the results in Table 1 shows that the all variables are relatively moderate around (3), respondents gave more attention to the relationship between entrepreneurial networks and small business owners' performance. Finally, the mean score of small business performance showed a moderately low level of 3. This result confirms respondents' perception of performance in this model context.

\subsection{Discussion}

The PLS algorithm results show that an estimated model fits the survey data, with $\mathrm{R}^{2}$ for small business owners' performance being 0.16 - this indicates moderate amounts of variance explained by the independent variables when adopting Cohen (1988) criterion. The value shows that the structural model has the capability to explain the acceptable variance level of small business owners' performance. Path coefficient $(\beta)$ and t value are both primarily utilized to test the proposed hypotheses in PLS (Henseler et al., 2009; Hair et al., 2014). After the generation of the path coefficients, each path coefficient can be evaluated in terms of its significance through the bootstrapping method that computes t-values.

On the whole, the statistical tests were assessed at the significance level of $5 \%$ through the use of two-tailed ttests as the entire hypotheses were proposed in a two-directional manner. The structural model estimates results are listed in Table 2 .

Table-2. Path Coefficients and Significant Level of Structure Model

\begin{tabular}{|c|c|c|c|}
\hline construct & $\boldsymbol{\beta}$ & T Statistics & P Value \\
\hline Entrepreneurial Networks $\quad$ ENO $-\mathrm{SBP}$ & 0.196 & 2.906 & 0.003 \\
\hline Government Intervention $(\mathrm{ENO})-(\mathrm{GI})-(\mathrm{SBP})$ & 0.542 & 1.155 & 0.24 \\
\hline
\end{tabular}

The path coefficients of the relationship among constructs are displayed, wherein the path form entrepreneurial networks to small business owners' performance is positive and insignificant at $(\beta=0.196 ; p<0.01)$. This reveals that as entrepreneurial networks increases, the performance increased with it and therefore, $\mathrm{H} 1 \mathrm{is}$ supported. A similar finding was obtained for government intervention in the interaction effect, The result of the PLS indicates that the estimated model fits the data well, wherein the $\mathrm{R}^{2}$ for small business performance was found to be 0.171 , which indicates moderate variance explained by the independent variables. Furthermore, Table 3 reveals that the research model was capable of explaining $17.1 \%$ of the total variance in small business performance, indicating that exogenous variables (entrepreneurial networks and government intervention) jointly explain $17.1 \%$ of the dependent variable (small business owners' performance).

Table-3. Variance Explained in the Endogenous Latent Variables

\begin{tabular}{l|l}
\hline Latent variable & Variance Explained R2 \\
\hline Small business owners' performance & $\% 17.1$ \\
\hline
\end{tabular}

A positive relationship was found between entrepreneurial networks and small business owners' performance that decreases when government intervention is high, but the interaction was insignificant at (standardized $\beta=$ $0.542, \mathrm{p}>0.10)$, negating the presence of a moderating effect. And as such $\mathrm{H} 2$ is not supported.

\section{Conclusion}

As the firm operates in a social context that may significantly impact its behavior and performance. However, a social network wherein the firm is integrated into also comprises resources and capabilities that can be considered as critical success factors for the firm. The relational and structural integration of the networks is significant drivers of firm performance. Furthermore, networks consist of a combination of strong and weak ties that can boost the economic performance of the owners. As such, managers and academicians are expanding efforts to understand the effects of networking on the performance of the firm. Most theoretical and empirical work dedicated to networks in entrepreneurship sought to explain the way networks impact the process of entrepreneurship and the way they result in superior firm outcomes, and the way entrepreneurial process and outcomes impact the network development as time passes.

\section{The Study Implications}

The study's conceptual framework was developed on the basis of empirical evidence and theoretical gaps found in literature and it is supported by the theoretical perspectives in the form of entrepreneurial networks. The study examined the moderating effect of government intervention to shed light on the relationship between entrepreneurial networks and the performance of small businesses owners. The contribution of this study is the explanation of the relevant theory (SNT) that addresses performance and was used to explain performance behaviour. This knowledge contributes to improving future research in the same context by adding to the knowledge of academicians in the country. The research findings may also be useful as a platform upon which future studies and literature reviews may be based.

\section{References}

Abou-Moghli, A. and A. Al Muala, 2012. Impact of entrepreneurial networks in the success of business on-going stage in Jordanian manufacturing companies. American Academic \& Scholarly Research Journal, 4(2): 13-17. View at Google Scholar

Armanurah, M., 2014. Evaluation of the implementation of program Siswaniag University Utara Malaysia, Phd Theses, University Kebangsaan Malaysia, 2014.

Arslan, A. and S. Staub, 2013. Theory X and theory Y type leadership behavior and its impact on organizational performance: Small business owners in the şishane lighting and chandelier district. Procedia-Social and Behavioral Sciences, 75: 102-111. View at Google Scholar View at Publisher 
Baron, R.A. and G.D. Markman, 2000. Beyond social capital: How social skills can enhance entrepreneurs' success. Academy of Management Perspectives, 14(1): 106-1 16. View at Google Scholar | View at Publisher

Batjargal, B., 2010. Network dynamics and new ventures in China: A longitudinal study. Entrepreneurship and Regional Development, 22(2): 139-153. View at Google Scholar | View at Publisher

Borg, E.A., 1991. Problem shifts and market research: The role of networks in business relationships. Scandinavian Journal of Management, 7(4): 285-295. View at Google Scholar | View at Publisher

Borgatti, S.P. and P.C. Foster, 2003. The network paradigm in organizational research: A review and typology. Journal of Management, 29(6): 991-1013. View at Google Scholar | View at Publisher

Chen, S., Z. Sun, S. Tang and D. Wu, 2011. Government intervention and investment efficiency: Evidence from China. Journal of Corporate Finance, 17(2): 259-271. View at Google Scholar $\mid$ View at Publisher

Cohen, J., 1988. Statistical power analysis for the behavioral sciences. Hillsdale, NJ: Lawrence Erlbaum Associates.

Davidsson, P. and B. Honig, 2003. The role of social and human capital among nascent entrepreneurs. Journal of Business Venturing, 18(3): 301-331. View at Google Scholar $\mid$ View at Publisher

Davis, J.L., R. Greg Bell, G. Tyge Payne and P.M. Kreiser, 2010. Entrepreneurial orientation and firm performance: The modera ting role of managerial power. American Journal of Business, 25(2): 41-54. View at Google Scholar $\mid$ View at Publisher

Elfring, T. and W. Hulsink, 2003. Networks in entrepreneurship: The case of high-technology firms. Small Business Economics, $21(4)$ : 409422. View at Google Scholar

Eniola, A.A. and H. Entebang, 2015. Government policy and performance of small and medium business management. International Journal of Academic Research in Business and Social Sciences, 5(2): 237-248. View at Google Scholar $\mid$ View at Publisher

Fatoki, O., 2012. The impact of entrepreneurial orientation on access to debt finance and performance of small and medium enterprises in South Africa. Journal of Social Sciences, 32(2): 121-131. View at Google Scholar | View at Publisher

Greve, A. and J.W. Salaff, 2003. Social networks and entrepreneurship. Entrepreneurship Theory and Practice, 28(1): 1-22. View at Google Scholar

Grimaldi, R., M. Kenney, D.S. Siegel and M. Wright, 2011. 30 years after Bayh-Dole: Reassessing academic entrepreneurship. Research Policy, 4O(8): 1045-1057. View at Google Scholar View at Publisher

Gulati, R. and M.C. Higgins, 2003. Which ties matter when? The contingent effects of interorganizational partnerships on IPO success. Strategic Management Journal, 24(2): 127-144. View at Google Scholar | View at Publisher

Hair, J.F., G.T.M. Hult, C.M. Ringle and M. Sarstedt, 2014. A primer on partial least squares structural equation modeling (PLS-SEM). Thousand Oaks: Sage Publications.

Hasanov, Z., A. Muysinaliyev and S. Aktamov, 2014. How is social capital associated with Innovation performance? Evidence from China chemical industry. International Journal of Social Science Research, 2(2): 1-19. View at Google Scholar | View at Publisher

Henseler, J., C.M. Ringle and R.R. Sinkovics, 2009. The use of partial least squares path modeling in international marketing: New challenges to international marketing. Emerald Group Publishing Limited. pp: 277-319.

Jack, S.L., 2010. Approaches to studying networks: Implications and outcomes. Journal of Business Venturing, 25(1): 120-137. View at Google Scholar $\mid$ View at Publisher

Kang, S.-C. and S.A. Snell, 2009. Intellectual capital architectures and ambidextrous learning: A framework for human resource management. Journal of Management Studies, 46(1): 65-92. View at Google Scholar | View at Publisher

Khayesi, J.N., G. George and J. Antonakis, 2014. Kinship in entrepreneur networks: Performance effects of resource assembly in Africa. Entrepreneurship Theory and Practice, 38(6): 1323-1342. View at Google Scholar

Koe, W.L., 2013. Entrepreneurial orientation (EO) and performance of government-linked companies (GLCs). Journal of Entrepreneurship, Management and Innovation, 9(3): 21-41. View at Publisher

Mason, M.C., J. Floreani, S. Miani, F. Beltrame and R. Cappelletto, 2015. Understanding the impact of entrepreneurial orientation on SMEs' performance. The role of the financing structure. Procedia Economics and Finance, 23: 1649-1661. View at Google Scholar $\mid$ View at Publisher

Michael, S.C. and J.A. Pearce, 2009. The need for innovation as a rationale for government involvement in entrepreneurship. Entrepreneurship and Regional Development, 2 1(3): 285-302. View at Google Scholar $\mid$ View at Publisher

Moeljadi, R., B. Sumiati, A. Suman and O.Y. Sherlinda, 2015. The effect of government as a moderating variable in the relationship between orientation entrepreneurship, innovation, and market orientation on business performance (Case Study: Tutul Village, Jember, and East Java). International Journal of Business, Economics and Law, 7(2): 18-25.

Mohd Shariff, M.N., C. Peou and J. Ali, 2010. Moderating effect of government policy on entrepreneurship and growth performance of smallmedium enterprises in Cambodia. International Journal of Business and Management Science, 3(1): 57-72. View at Google Scholar

Moran, P., 2005. Structural vs. Relational embeddedness: Social capital and managerial performance. Strategic Management Journal, 26(12): 1129-1 151. View at Google Scholar | View at Publisher

Onwukwe, V. and M. Ifeanacho, 2011 . Impact of government intervention on the growth of small and medium scale enterprises in Imo State. International Journal of Research in Commerce, Economics \& Management, 1(7): 1-5. View at Google Scholar

Premaratne, S.P., 2002. Entrepreneurial networks and small business development: The case of small enterprises in Sri Lanka. Eindhoven: Technische Universiteit Eindhoven.

Rauch, A., W.J. Andreas, F. Michael and G. Lumpkin, 2004. Entrepreneurial orientation and business performance: Cumulative empirical evidence. Frontiers of Entrepreneurship Research, 6(1): 164-177.

Ruslan, M.F., A.A. Senin and K. Soehod, 2014. In: Technological determinants of green production adoption by Malaysian small and medium enterprises (SMEs): A conceptual framework. International Conference on Business, Management \& Corporate Social Responsibility (ICBMCSR'14).

Sadler, A. and S. Chetty, 2001. The impact of networks on New Zealand firms. Journal of Euromarketing, 9(2): 37-58. View at Google Scholar View at Publisher

Tilley, F., 1999. The gap between the environmental attitudes and the environmental behaviour of small firms. Business Strategy and the Environment, 8(4): 238-248. View at Google Scholar | View at Publisher

UNDP, 2011. United Nations Developmenr Program. Jordan Human Development Report. New York.

Wagaman, M.A. and E.A. Segal, 2014. The relationship between empathy and attitudes toward government intervention. Journal of Sociology and Social Welfare, 41: 91. View at Google Scholar

Walker, E. and A. Brown, 2004. What success factors are important to small business owners? International Small Business Journal, 22(6): 577-594. View at Google Scholar | View at Publisher

Watson, J., 2007. Modeling the relationship between networking and firm performance. Journal of Business Venturing, 22(6): 85 2-874. View at

Wiklund, J. and D. Shepherd, 2005. Entrepreneurial orientation and small business performance: A configurational approach. Journal of Business Venturing, 20(1): 71-91. View at Google Scholar $\mid$ View at Publisher

Zaheer, A. and G.G. Bell, 2005. Benefiting from network position: Firm capabilities, structural holes, and performance. Strategic Management Journal, 26(9): 809-825. View at Google Scholar | View at Publisher

Zahra, S.A. and M. Wright, 2011. Entrepreneurship's next act. Academy of Management Perspectives, 25(4): 67-83. View at Google Scholar $\mid$ View at Publisher 